\title{
The Experience of Transferee Courts Under the Multidistrict Litigation Act
}

The Multidistrict Litigation Act ${ }^{1}$ evolved from the experience of the federal judiciary in handling the avalanche of litigation resulting from the electrical equipment antitrust cases, in which over nineteen hundred related treble damage actions were filed within a twelve-month period in thirty-six district courts. ${ }^{2}$ To expedite the administration of these suits, the Judicial Conference of the United States created the Co-ordinating Committee for Multiple Litigation. Under its direction, and through the voluntary cooperation of the district judges, discovery for all parties was conducted on a unified, nationwide basis. ${ }^{3}$ At the completion of pretrial proceedings, cases were transferred according to product line to selected transferee districts for trial. ${ }^{4}$ All cases were either tried or settled within six years, the not unusual time span for disposition of a single protracted antitrust action.

Perceiving a continuing need for such pretrial management, the Committee recommended the creation of a permanent mechanism for mandatory transfer of related multidistrict civil actions to a single district for pretrial proceedings. ${ }^{5}$ This proposal eventually resulted in the enactment of the present section 1407 of the Judicial Code, which establishes the Judicial Panel on Multidistrict Litigation.

The purpose of pretrial transfer under section 1407 is to promote efficient judicial administration without infringing on the rights of the parties. ${ }^{6}$ The subsequent experience of the transferee courts has demonstrated that multidistrict transfer is a valuable but incomplete device toward this.end. In practice, the statutory mechanism has not functioned as Congress intended. After an initial period of hesitancy, transferee courts have steadily increased their control over pretrial proceedings far

128 U.S.C. § 1407 (1970).

2 S. REP. No. 454, 90th Cong., Ist Sess. 3 (1967); Neal \& Goldberg, The Electrical Equipment Antitrust Cases: Novel Judicial Administration, 50 A.B.A.J. 621 (1964).

3 Peterson \& McDermott, Multidistrict Litigation: New Forms of Judicial Administration, 56 A.B.A.J. 737, 737-38 (1970).

4 Transfers were made under the change-of-venue provision, 28 U.S.C. § 1404(a) (1970). For a discussion of the relationship between this Act and section 1407, see text at notes 13-15 infra.

5 Peterson \& McDermott, supra note 3, at 740 .

6 Levy, Complex Multidistrict Litigation and the Federal Courts, 40 FORDhAM L. REv. 41 (1971). 
beyond the role envisioned by the drafters of the statute. Cases, once centralized, have not been remanded to their original districts at the completion of pretrial proceedings, and transfer for the limited purpose of pretrial proceedings has become functionally equivalent to transfer for all purposes, including trial on substantive legal issues. ${ }^{7}$ These interrelated developments have greatly altered the nature of a section 1407 transfer and necessitate reevaluation of the role of the Judicial Panel in terms of the actual consequences of pretrial transfer.

This comment will explore the first four years of transferee court activity under section 1407 . The central focus will be on the current practices and procedures adopted by transferee judges, their increasing authority over pretrial proceedings, and their attempts to extend the advantages of multidistrict transfer beyond the pretrial stage. Finally, proposals for modification of the statute will be suggested to help effectuate its underlying purposes.

\section{Activity of the Judicial Panel}

\section{A. The Statutory Requirements}

Section 1407(a) provides:

When civil actions involving one or more common questions of fact are pending in different districts, such actions may be transferred to any district for coordinated or consolidated pretrial proceedings. Such transfers shall be made by the judicial panel on multidistrict litigation authorized by this section upon its determination that transfers for such proceedings will be for the convenience of parties and witnesses and will promote the just and efficient conduct of such actions. ${ }^{8}$

The Judicial Panel consists of seven federal court of appeals and district court judges appointed by the Chief Justice of the United States. ${ }^{9}$ In any action in which transfer might be appropriate, the Panel, on its own motion or that of any party, conducts hearings in which all parties subject to transfer may participate. ${ }^{10}$ On the record made at the hearing,

7 Although Congress envisioned that most transferred cases would be returned to the transferor districts, the most intriguing aspect of the operation of section 1407 is the almost total absence of reported cases that have been remanded. See text at notes 116-27 infra.

828 U.S.C. \& I407(a) (1970). The mechanics of multidistrict transfer are discussed in Levy, supra note 6, and Comment, Pre-Trial Consolidation in Complex Federal MultiDistrict Litigation, 6 Colum. J.L. \& Socias ProB. 433 (1970). For an earlier analysis of the statute, see Comment, Consolidation of Pretrial Proceedings Under Proposed Section 1407 of the Judicial Code: Unanswered Questions of Transfer and Review, 33 U. CrI. L. REv. 558 (1966).

928 U.S.C. \& 1407(d) (1970).

10 Id. $\S 1407$ (c). 
the Panel may order transfer of multidistrict cases to any district for coordinated or consolidated pretrial proceedings. ${ }^{11}$ It assigns the litigation to a single transferee judge, who conducts all pretrial procedures, including discovery and the taking of depositions. After pretrial proceedings are completed, each action not previously terminated in the transferee court must be remanded to the district from which it was transferred.12

Section 1407 makes transfer possible without regard to venue. ${ }^{13}$ Comparison with preexisting change-of-venue provisions under section $1404^{14}$ reveals the flexibility of multidistrict transfer. Although section 1404(a) allows transfer of actions for all purposes, including trial, to a district better suited to handle them, not all related cases can be transferred,,$^{15}$ and there is no provision for coordinated management of transfer decisions. Section 1407 thus extends transfer to a broader range of cases, but for a more restricted purpose; it gives the judiciary an additional method of dealing with multiple litigation where complete consolidation for both pretrial proceedings and trial is either impossible or undesirable.

\section{B. Benefits and Costs of Pretrial Transfer}

The primary objective of the Judicial Panel in applying section 1407 is the efficient employment of limited judicial resources. ${ }^{16}$ Transfer of

$11 \mathrm{Id}$. Review of orders to transfer is by extraordinary writ and must be filed in the court of appeals having jurisdiction over the transferee court. Id. $\S 1407$ (e). In no reported case has this procedure been employed.

12 Id. $\S 1407$ (a). The Judicial Panel also prescribes rules for the conduct of its business. Id. $\S 1407(f)$. The Rules of Procedure of the Judicial Panel on Multidistrict Litigation appear at 53 F.R.D. 119 (1971); previous editions of the rules appear at 50 F.R.D. 203 (1970), 47 F.R.D. 377 (1969), and 44 F.R.D. 389 (1968).

28 U.S.C. $\$ 1407(\mathrm{~g})(1970)$ exempts government antitrust actions seeking injunctive or other equitable relief from pretrial transfer; however, this section does not exclude transfer of government damage suits, in which the government in effect stands in the shoes of a private party. S. REP. No. 454, supra note 2 , at 6 . Private litigants often recognize the primacy of the government claim and agree to transfer of their cases to the district in which the government filed its action for pretrial proceedings. See In re Alsco-Harvard Fraud Litigation, 325 F. Supp. 315, 316 (J.P.M.L. 1971).

13 In re Revenue Properties Co., 309 F. Supp. 1002, 1004 (J.P.M.L. 1970).

1428 U.S.C. § 1404(a) (1970). Section 1404(a) was adopted in 1948 and supersedes the doctrine of forum non conveniens in the federal courts. C. WRIGHT, FEDERAL CourTs 164-70 (2d ed. 1970). See Note, Consolidation and Transfer in the Federal Courts: 28 U.S.C. Section 1407 Viewed in Light of Rule 42(a) and 28 U.S.G. Section 1404(a), 22 HAstings L.J. 1289 (1971).

15 Hoffman v. Blaski, 363 U.S. 335 (1960), restricts transfers under section 1404(a) to districts in which the action could originally have been brought.

16 Levy, supra note 6, at 49. Actions will not be transferred when discovery is proceeding with a minimal degree of judicial supervision, despite their multidistrict character and 
all related cases to one district court results in a significant savings in judicial manpower by eliminating the duplication of effort inherent in simultaneous consideration of identical problems by several district court judges. The man-hours thus conserved are available to reduce docket congestion in the transferor districts.

An alternate aim of section 1407 is to eliminate the potential for conflicting contemporaneous pretrial rulings by district courts in related civil actions. ${ }^{17}$ To accomplish this purpose, appeals from transferee court decisions must be filed in the court of appeals for the transferee district rather than in those of the transferor districts; ${ }^{18}$ a multiplicity of review proceedings is thereby avoided and the possibility of conflicting appellate rulings minimized. ${ }^{19}$

Although designed primarily to achieve efficient judicial administration, section 1407 also requires that transfer serve the convenience of the parties and witnesses. ${ }^{20}$ Among the benefits accruing to the parties, the most significant is the reduction in the costs of prosecuting or defending actions. Multiple, uncoordinated pretrial litigation in separate districts entails exorbitant expenditures of time and resources in sequential resolution of identical problems. Under section 1407 transfer, these litigation expenses are normally reduced through efficient judicial decision making, elimination of duplicative discovery, and prevention of

the presence of common questions of fact. See, e.g., In re Photocopy Paper, 305 F. Supp. 60, 62 (J.P.M.L. 1969); In re Texas Concrete Pipe, 302 F. Supp. 1342, 1343 (J.P.M.L. 1969).

17 In re Plumbing Fixtures, 298 F. Supp. 484, 490-92 (J.P.M.L. 1968); H.R. REP. No. 1130, 90th Cong., 2d Sess. 2 (1968).

18 Utah v. American Pipe \& Constr. Co., 316 F. Supp. 837, 839 (C.D. Cal. 1970) (West of Rockies Concrete Pipe). The order of transfer issued by the Panel is filed in the office of the clerk of the transferee court, 28 U.S.C. $\S 1407$ (c) (1970); venue and jurisdiction is vested in the transferee court and thus in the court of appeals for that district. Utah v. American Pipe \& Constr. Co., supra.

19 Conservation of judicial resources is also promoted by the selection of the transferee district; the Judicial Panel frequently transfers multidistrict cases to a judge already familiar with the factual and legal problems in the litigation because of his previous experience with one or more of the related actions. E.g., In re Carrom Trademark Litigation, 322 F. Supp. 1016 (J.P.M.L. 1971); In re IBM, 302 F. Supp. 796 (J.P.M.L. 1969). But see In re Water Meters, 304 F. Supp. 873 (J.P.M.L. 1969).

20 Levy, supra note 6, at 50; see In re Plumbing Fixtures, 298 F. Supp. 484, 499 (J.P.M.L. 1968) (quoting Report of the Co-ordinating Committee on Multiple Litigation Recommending New Section 1407, Title 28). Section 1407 was amended to include the provision requiring transfer to serve the convenience of the parties and witnesses. According to the legislative history,

[t] he main purpose of transfer for consolidation or coordination of pretrial proceedings is to promote the ends of efficient justice, but the convenience of parties and witnesses should also be a factor in determining whether such transfer should be made. Although implicit in the bill, as introduced, this amendment makes it clear that the convenience of parties and witnesses shall be weighed as a factor in determining whether transfer should be made.

S. REP. No. 454 , supra note 2 , at 2. 
inconsistent trial court and appellate decisions. ${ }^{21}$ Although certain parties may incur additional expenses if their cases are transferred, these costs are usually limited to travel by their attorneys to the transferee district for pretrial conferences ${ }^{22}$ and pale into insignificance beside the overall savings from and convenience of centralized pretrial proceedings. ${ }^{23}$

An additional savings to the parties is achieved through the appointment by the transferee judge of liaison counsel for each side in order to conduct the routine paperwork and minutiae of pretrial proceedings. ${ }^{24}$ This procedure not only minimizes the cost of the litigation, but also allows parties with few resources to be fully represented by counsel after transfer. ${ }^{25}$

The primary disadvantage of section 1407 transfer is that it deprives plaintiffs of the right to conduct pretrial proceedings in any district in which they could have brought an action and forces defendants to litigate in a district in which the could not have been sued. ${ }^{26}$ The parties'

21 For the parties as a group, centralized discovery results in shared costs for common information and more immediate access to the witnesses and documents of the other side. Centrally conducted deposition taking, for example, eliminates delay ensuing from individual interrogation of the same deponent. In the Plumbing Fixtures litigation, thirtyfour lawyers required twenty-three days to take the deposition of one witness. Wall Street Journal, Jan. 18, 1972, at 13, col. 2 (Midwest ed.). Separate deposition taking by each of more than three hundred plaintiffs would have produced intolerable delay in the completion of pretrial proceedings. For similar experience in the electrical equipment cases, see Hearings on S. 3815 Before the Subcomm. on Improvements in Judicial Machinery of the Senate Comm. on the Judiciary, 89th Cong., Ist Sess., ser. 18, pt. 1, at 26-27 (1966) (testimony of Charles A. Bane) [hereinafter cited as Hearings on S. 3815].

22 In re Plumbing Fixtures, 302 F. Supp. 795, 796 (J.P.M.L. 1969). The transferee judge can schedule conferences to minimize even this expense. See In re San Juan, P.R. Air Crash Disaster, 316 F. Supp. 981, 982 (J.P.M.L. 1970).

23 In re Antibiotic Drugs, 295 F. Supp. 1402, 1404 (J.P.M.L. 1968); In re Plumbing Fixtures, 302 F. Supp. 795 (J.P.M.L. 1969). The convenience of witnesses is an issue rarely raised in opposition to multidistrict transfer except in mass tort cases, in which the witnesses and information relating to the victim's life expectancy, medical history, and future earning power are located in the transferor district. See In re Air Crash at Las Vegas, Nev., 336 F. Supp. 414, 415 (J.P.M.L. 1972); In re Air Crash Disaster at Hanover, N.H., MDL Docket No. 43 (D.N.H., filed June 29, 1971); text at notes 128-32 infra.

24 Panel Rule 5(d) empowers the transferee judge to select liaison counsel. Such counsel receive notices from the court on behalf of all counsel, arrange distribution of notices to all other counsel, and act as spokesmen at pretrial conferences. Liaison counsel coordinate discovery to avoid repetition and insure the orderly and expeditious conduct of discovery and pretrial hearings. See Practice and Procedure Order upon Transfer Pursuant to 28 U.S.C. \& 1407(a), In re Santa Monica Air Crash Disaster, MDL Docket No. 34 (G.D. Cal., filed May 25, 1970).

25 The interest of the parties in minimizing the costs of the litigation is legitimate and deserves judicial protection. See In re "East of the Rockies" Concrete Pipe, 302 F. Supp. 244, 249 (J.P.M.L. 1969).

26 See Comment, Pre-Trial Consolidation in Complex Federal Multi-District Litigation, supra note 8, at 445. Another possible source of inconvenience and inefficiency is the poten- 
rights, however, are protected upon transfer. The transferee court must apply the substantive law of the transferor district in each case; and the plaintiffs' choice-of-law preference among districts, especially with regard to wrongful death damage limitations, is respected..$^{27}$

When the interests of the parties conflict, the dispute before the Judicial Panel often concerns the selection of the proper transferee district rather than the appropriateness of pretrial transfer. ${ }^{28}$ In making its decision, the Panel must weigh the comparative advantages of potential transferee forums and determine which will be most convenient for the aggregate of the parties. ${ }^{29}$ The Panel frequently transfers cases to the district in which discovery has advanced furthest ${ }^{30}$ or in which the most complete store of documents is available. ${ }^{31}$

In selecting the transferee district, the Judicial Panel has realized that many factors serving the interests of the parties also promote judicial efficiency. The status of the prospective transferee court's docket is particularly important, ${ }^{32}$ since both the parties and the judiciary want to avoid assignment of the litigation to an already heavily burdened judge.

tial for delay in the disposition of cases by untimely entry of a transfer order. Because trial would be delayed, the Judicial Panel will not transfer a case in which pretrial proceedings are nearly complete. E.g., In re Concrete Pipe, 297 F. Supp. 1125, 1126 (J.P.M.L. 1968). The Panel will not transfer cases if it would interfere with normal appellate review of transferor court rulings, In re Plumbing Fixtures, 298 F. Supp. 484, 496 (J.P.M.L. 1968), or with reasonable settlement activity, see In re Hotel Tel. Charge Antitrust Litigation, MDL Docket No. 89 (J.P.M.L., filed Mar. 30, 1972); In re Air Crash at New Orleans, La., 331 F. Supp. 554 (J.P.M.L. 1971). Nor will it order transfer when a voluntary plan for pretrial coordination of discovery efforts is succeeding, see In re Kauffman Mutual Fund Actions, 337 F. Supp. 1337, 1339 (J.P.M.L. 1972), or when there is a reasonable prospect that resolution of change-of-venue motions will eliminate the multidistrict character of the litigation, In re Deering Milliken Patent, 328 F. Supp. 504 (J.P.M.L. 1970). But see In re Government Auto Fleet Sales, 328 F. Supp. 218, 219 (J.P.M.L. 1971).

27 Van Dusen v. Barrack, 376 U.S. 612 (1964); see Hearings on S. 3815, supra note 21, at 13 (testimony of Dean Phil C. Neal).

28 In re Air Fare Litigation, 322 F. Supp. 1013, 1015 (J.P.M.L. 1971).

29 In re "East of the Rockies" Concrete Pipe, 302 F. Supp. 244, 253 (J.P.M.L. 1969) (Weigel, $\mathrm{J}$., concurring), outlines the balancing process and provides a comprehensive discussion of the various factors weighed by the Panel in making a transfer decision.

30 E.g., In re Antibiotic Drugs, 295 F. Supp. 1402, 1403 (J.P.M.L. 1968).

31 Appropriate considerations in selecting the transferee district include the location of grand jury records, e.g., In re Motor Vehicle Air Pollution Control Equip., $311 \mathrm{~F}$. Supp. 1349 (J.P.M.L. 1970); the site of pending reorganization proceedings, e.g., In re Penn Central Sec. Litigation, 322 F. Supp. 1021 (J.P.M.L. 1971); the situs of disasters, e.g., In re Air Crash Disaster at Ardmore, Okla., 295 F. Supp. 45 (J.P.M.L. 1968); and the location of corporate files, e.g., In re Protection Devices \& Equip., 295 F. Supp. 39 (J.P.M.L. 1968).

In nationwide litigation, the Panel will often choose a centrally located transferee district in order to reduce the expense and inconvenience of counsel. See In re Butterfield Patent Infringement, 328 F. Supp. 513 (J.P.M.L. 1970).

32 See In re Career Academy Antitrust Litigation, MDL Docket No. 98 (J.P.M.L., filed Apr. 28, 1972); In re Silver Bridge Disaster, 311 F. Supp. 1345 (J.P.M.L. 1970). 
When, as often occurs, no judge in the district most appropriate for pretrial proceedings is able to support a substantial addition to his case load, section 1407(b) permits the Panel to assign a judge to the transferee district on a temporary basis. ${ }^{33}$ This procedure allows optimal use of judicial resources to expedite disposition of the cases; judges and cases can be transferred throughout the country to conduct pretrial proceedings in the most expeditious manner. ${ }^{34}$

Transfer does not, of course, necessarily serve the interests of justice, efficiency, and convenience of the parties simply because common questions of fact are present. ${ }^{35}$ The crucial question remains whether the economies of transfer outweigh the resulting inconvenience to the parties. ${ }^{36}$ The Judicial Panel must decide whether transfer will serve the

3328 U.S.C. § 1407(b) (1970).

34 The Chief Justice has made eight intercircuit assignments under 28 U.S.C. \$ 292(d) (1970) and one under 28 U.S.C. § 294(d) (1970) (In re Cross-Florida Barge Canal Litigation, 329 F. Supp. 543 (J.P.M.L. 1971)); manpower has been transferred from less congested circuits to those with substantial docket delays. The Second Circuit has had outside transferee judges assigned three times, and the District of Columbia, First, Third, Fifth, Ninth, and Tenth Circuits have had one judge assigned to each.

The intracircuit assignment under 28 U.S.G. § 292(b) (1970) has been used five times, all but once to transfer manpower from the less congested districts of the Ninth Circuit to the Northern District of California, which has been laboring under a substantial backload. The exception is In re Silver Bridge Disaster, 311 F. Supp. 1345 (J.P.M.L. 1970).

Members of the Panel have been designated transferee judges in In re Admission Tickets, 302 F. Supp. 1339 (J.P.M.L. 1969) (Robson, J.); In re San Juan, P.R. Air Crash Disaster, 316 F. Supp. 981 (J.P.M.L. 1970) (Weinfeld, J.); and In re Penn Central Sec. Litigation, 322 F. Supp, 1021 (J.P.M.L. 1971) (Lord, J.).

35 According to the legislative history, section 1407 was not to be used where only two or three cases were pending in different districts, since in such a situation there was no need for centralized judicial management. H.R. REP. No. 1130, suppra note 17, at 4; S. REP. No. 454, supra note 2, at 4. Transfer was denied on this basis in In re Scotch Whiskey, 299 F. Supp. 543 (J.P.M.L. 1969) (two cases in two districts); In re Homemakers Franchise Litigation, 337 F. Supp. 1342 (J.P.M.L. 1972); In re Iowa Beef Packers, Inc., 309 F. Supp. 1259 (J.P.M.L. 1970); and In re Photocopy Paper, 305 F. Supp. 60 (J.P.M.L. 1969).

An exception to this principle was made for a few cases sharing unusually complex questions of fact. H.R. REP. No. 1130, supra note 17, at 4. In In re IBM, 302 F. Supp. 796 (J.P.M.L. 1969), three cases requiring extensive and complex discovery were held to be within this" exception and were transferred for consolidated or coordinated pretrial proceedings. Extension of the $I B M$ doctrine to justify transfer in cases sharing far less complex factual questions has minimized the operational effectiveness of the Scotch Whiskey doctrine. See In re Cross-Florida Barge Canal Litigation, 329 F. Supp. 543 (J.P.M.L. 1971) (two cases); In re CBS Licensing Antitrust Litigation, 328 F. Supp. 511 (J.P.M.L. 1971) (two cases); In re Brown Co. Sec. Litigation, 325 F. Supp. 307 (J.P.M.L. 1971) (four cases); In re Willingham Patent, 322 F. Supp. 1019 (J.P.M.L. 1971) (three cases); In re Carrom Trademark Litigation, 322 F. Supp. 1016 (J.P.M.L. 1971) (four cases).

36 A dispute has arisen within the Panel, for example, on the substantiality of common factual questions sufficient to justify transfer. The Panel has transferred several dockets of patent infringement cases in which the defendants have challenged the validity of the patent. The majority has found that the common factual question of patent validity alone justifies transfer, but the dissenters argue that the essential question in the cases is patent 
overall convenience of all parties to the litigation. ${ }^{37}$ In balancing these interests, the transfer order often relies on the transferee court's ability to resolve the complex problems posed by wholesale transfer of cases with conflicting legal theories and discovery demands. The effectiveness of section 1407 must, therefore, depend on the extent to which transferee courts have been able to conduct transferred litigation economically and efficiently.

\section{Actrvity of Transferee Courts}

Section 1407(a), as noted, provides that related multidistrict civil actions may be transferred to any district for coordinated or consolidated pretrial proceedings. The House Report defines pretrial proceedings as "the practice and procedure which precede the trial of an action." $38 \mathrm{Al}$ though the term obviously encompasses deposition and discovery, the extent to which it includes the power to rule on questions of law has been challenged by some judges. ${ }^{39}$ The House Report states, however, that the transferee judge shall have the same power as any other district judge to make dispositive legal rulings. ${ }^{40}$ The Judicial Panel has simi-

infringement, which is more suited to local discovery in the districts in which the actions were brought. See In re Embro Patent Infringement Litigation, 328 F. Supp. 507, 509 (J.P.M.L. 1971) (Weigel, J., dissenting); In re Willingham Patent, 322 F. Supp. 1019, 1021 (J.P.M.L. 1971); In re Carrom Trademark Litigation, 322 F. Supp. 1016, 1019 (J.P.M.L. 1971); In re Butterfield Patent Infringement, 328 F. Supp. 513, 515 (J.P.M.L. 1970). But see In re Kaehni Patent, 311 F. Supp 1342, 1344 (1970) (Weigel, J., concurring), in which the question of infringement was common to all defendants because it allegedly involved a single device.

37 In re Library Editions of Children's Books, 297 F. Supp. 385, 386 (J.P.M.L. 1968). Transfer may inconvenience an individual party, since his interests favor having all proceedings in his action handled in his district; the Panel, however, rejects the "worm's eye view" of section 1407 and considers whether the aggregate convenience of parties and witnesses will be served by transfer to a particular forum. See In re IBM, MDL Docket No. 18 (J.P.M.L., filed Apr. 19, 1972).

38 H.R. REP. No. 1130, stpra note 17, at 3.

39 "The Powers of Transferee Judges," an address prepared in May, 1971, by Judge Philip Neville of the District of Minnesota, responded to numerous questions raised about the power of transferee judges to rule on questions of law. A copy of the address is on file at The University of Chicago Law Review.

40 H.R. REP. No. 1130, supra note 17, at 3; see Hearings on S. 3815, supra note 21 , at 13-14 (testimony of Dean Phil C. Neal). Nor can only the common questions of fact be transferred to the transferee forum, with the remaining issues left in the transferor courts. Section 1407 does not authorize the severance of questions of law, but requires that they be transferred to the transferee court. In re Revenue Properties Co., 333 F. Supp. 558 (J.P.M.L. 1971).

28 U.S.C. $\& 1407$ (a) (1970) allows the Panel to exempt any claims, counter-claims, crossclaims, or third-party claims from transfer with the rest of the action. See In re Penn Central Sec. Litigation, 325 F. Supp. 309 (J.P.M.L. 1971); In re Antibiotic Drugs, 309 F. Supp. 155 (J.P.M.L. 1970). 
larly noted that pretrial, as an adjective, describes all judicial proceedings before trial, ${ }^{41}$ including motions to dismiss and motions for summary judgment. ${ }^{42}$ Nevertheless, Congress perceived the power to make legal rulings only as an adjunct to the discovery process, a practical necessity if factual discovery was to be accomplished. ${ }^{43}$ The activity of transferee courts under section 1407 demonstrates the erosion of this principle.

\section{A. Discovery}

Control of discovery proceedings is the essence of the transferee judge's role, and his powers in this area are comprehensive. Although the Federal Rules of Civil Procedure anticipate that discovery will be directed by the parties, the Manual for Complex and Multidistrict Litigation, ${ }^{44}$ published by the Co-ordinating Committee as a guide to transferee judges, recommends strict judicial supervision of all aspects of pretrial proceedings. ${ }^{45}$ Naturally, the transferee judge has full power to deal with all legal problems arising in discovery. ${ }^{46}$

41 In re Plumbing Fixtures, 298 F. Supp. 484, 495-96 (J.P.M.L. 1968).

42 Panel Rule 15(e) provides that "actions terminated in the transferee court by settlement, dismissal or summary judgment shall not be remanded by the Panel and shall be dismissed by the transferee court."

43 Hearings on S. 3815, supra note 21, at 14 (testimony of Dean Neal); id. at 21-22 (testimony of Judge William H. Becker).

441 Moore, Federal Practice pt. 2 (2d ed. 1971).

45 Id. § 1. 1; see In re Library Editions of Children's Books, 297 F. Supp. 385, 386 (J.P.M.L. 1968). Section 1407 transfer does not terminate discovery orders issued in the transferor courts; they remain in effect until the transferee judge assumes effective control of the litigation at the first pretrial conference. In re Master Key, 320 F. Supp. 1404, 1407 (J.P.M.L. 1971).

46 Issues decided by transferee judges and reported include the following:

Attorney-client privilege: Pfizer, Inc. v. Lord, 5 TRADE REg. REP. (1972 Trade Cas.) If 73,847 (8th Gir. Feb. 15, 1972) (mandamus directing transferee judge to vacate discovery order); Jack Winter, Inc. v. Koratron Co., 54 F.R.D. 44 (N.D. Cal. 1971); Jack Winter, Inc. v. Koratron Co., 50 F.R.D. 225 (N.D. Cal. 1970); Illinois v. Harper \& Row Publishers, Inc., 50 F.R.D. 37 (N.D. Ill. 1969), mandamus denied sub. nom. Harper \& Row Publishers, Inc. v. Decker, 423 F.2d 487 (7th Cir. 1970), aff'd by an equally divided Court, 400 U.S. 348 (1971) (Children's Books).

Public policy privilege: In re Four Seasons Sec. Laws Litigation, CCH FED. SEC. L. REP. If 93,400 (W.D. Okla. Mar., 1972); In re Puerto Rico Air Disaster Litigation, 11 Av. Cas. 18,130 (D.P.R. 1971); In re Puerto Rico Air Disaster Litigation, 11 Av. Cas. 18,125 (D.P.R. 1971); Farrell v. Piedmont Aviation, Inc., 50 F.R.D. 385 (W.D.N.G. 1969) (Hendersonville Air Crash Disaster).

Venue discovery: ABC Great States, Inc. v. Globe Ticket Co., 304 F. Supp. 1052 (N.D. IIl. 1969) (Admissions Tickets).

Motions to compel answers to interrogatories: In re Master Key, 53 F.R.D. 87 (D. Conn. 1971); Philadelphia Housing Authority v. American Radiator \& Standard Sanitary Corp., 50 F.R.D. 13 (E.D. Pa. 1970), aff'd sub. nom. Mangano v. American Radiator \& Standard Sanitary Corp., 438 F.2d 1187 (3d Cir. 1971).

For other pretrial rulings, see Weidberg v. American Airlines, Inc., 336 F. Supp. 407 (N.D. Ill. 1972) (Air Fare) (motion to stay proceedings); California v. American Radiator 
The Judicial Panel leaves the resolution of conflicting demands of the parties to the discretion of the transferee judge, ${ }^{47}$ who, by virtue of his day-to-day contact with the litigation, is in the best position to determine the most just and efficient method of conducting discovery. ${ }^{48}$ The Panel also will not hesitate to assign cases involving different legal questions but common factual bases to a single judge for coordinated or consolidated pretrial proceedings. ${ }^{49}$ The transferee judge can decide which issues are subject to consolidated discovery ${ }^{50}$ and determine the best procedure for scheduling noncommon discovery. ${ }^{51}$ By this method, he can prevent the more complex discovery issues from engulfing and impeding the development of other cases. ${ }^{52}$

Without interfering with the transferee judge's discretionary author-

\& Standard Sanitary Corp., 309 F. Supp. 1057 (E.D. Pa. 1969) (Plumbing Fixtures) (motion to amend complaint); Control Data Corp. v. IBM, 306 F. Supp. 839 (D. Minn. 1969) (motion to strike allegations from pleadings).

47 The Panel has neither the power nor the disposition to instruct the transferee judge how to conduct pretrial proceedings. In re Plumbing Fixtures, 298 F. Supp. 484, 489 (J.P.M.L. 1968).

48 In re Penn Central Sec. Litigation, 333 F. Supp. 382 (J.P.M.L. 1971).

49 See In re Air Crash Disaster at the Greater Cincinnati Airport, 295 F. Supp. 51 (J.P.M.L. 1968).

50 Coordinated pretrial proceedings are appropriate where the transferred cases include two or more distinct groups of cases with potential conflicts of interest or conflicts in discovery objectives but with substantial common questions of fact. The transferee judge can consolidate the proceedings within each group and determine the degree of common discovery appropriate between the groups. The Panel will not attempt to anticipate the degree of coordination or consolidation that may be desirable in transferred cases. See In re Penn Central Sec. Litigation, 322 F. Supp. 1021, 1023 n.4 (J.P.M.L. 1971).

Transfer for coordinated pretrial proceedings has been appropriate in In re Four Sea. sons Sec. Laws Litigation, 328 F. Supp. 221 (J.P.M.L. 1971); In re Penn Central Sec. Litigation, supra; In re Grain Shipments, 319 F. Supp. 533 (J.P.M.L. 1970); In re SeeburgCommonwealth United Merger, 312 F. Supp. 909 (J.P.M.L. 1970); and In re Revenue Properties Co., 309 F. Supp. 1002 (J.P.M.L. 1970).

51 In re Grain Shipments, 319 F. Supp. 533 (J.P.M.L. 1970). The transferee judge can also determine which questions should be left for local discovery in the transferor districts after remand of the actions. See In re Frost Patent, 316 F. Supp. 977, 980 (J.P.M.L. 1970).

52 See In re Seeburg-Commonwealth United Merger, 312 F. Supp. 909 (J.P.M.L. 1970). Panel Rule I defines a "tag-along" case as an action sharing factual questions common to actions previously transferred under section 1407, but which was filed or came to the attention of the Panel after the initial hearing. Under Panel Rule 12, these actions are automatically transferred to the transferee court upon issuance of a conditional transfer order by the Clerk of the Panel unless the parties object within fifteen days. A frequent objection to transfer in tag-along cases is the asserted difficulty and expense in catching up with already completed discovery. The Panel has held that these difficulties are outweighted by the benefits to all parties in centralizing the litigation. In re Koratron Patent Litigation, 327 F. Supp. 559 (J.P.M.L. 1971). The transferee judge has great latitude to make previously produced discovery available to all new parties and to allow them to supplement it, if necessary, and thus obtain an earlier trial. Id. at 560. See also In re Antibiotic Drugs, $327 \mathrm{~F}$. Supp. 617 (J.P.M.L. 1971). 
ity, the Judicial Panel keeps informed of the progress of pretrial proceedings. The Panel does not serve as a court of appeals for decisions of the transferee courts, ${ }^{53}$ but does exercise some supervision over the handling of pretrial proceedings to insure that they are carried out justly and efficiently. ${ }^{54}$ The Panel also conducts meetings to inform transferee judges of the experience of other districts and to assist them in dealing with the unique pretrial problems posed by multidistrict transfer. ${ }^{\mathbf{5 5}}$

\section{B. Venue and Jurisdictional Problems}

The authority to effect a section 1407 transfer is not vitiated by either lack of proper service, lack of notice of the transfer hearing, or improperly laid venue in the transferor district. ${ }^{56}$ In the Children's Book litigation, ${ }^{57}$ for example, the Judicial Panel held that it could transfer a case even if some named codefendants had been neither served with process nor given notice of the transfer hearing. Since transfers under both section 1404(a) and section 1406(a) ${ }^{58}$ may be made without personal jurisdiction over the codefendant, ${ }^{59}$ the Panel concluded that Gongress intended section 1407 to operate similarly. To restrict transfer to cases in which all defendants have been served would, according to the Panel, frustrate centralized pretrial management without meaningfully advancing any other substantial interest. ${ }^{60}$ Moreover, a transfer under section 1407 would not eliminate the requirement that proper service

53 See In re Plumbing Fixtures, 332 F. Supp. 1047 (J.P.M.L. 1971).

54 See Hearings on $S .3815$, supra note 21 , at 23 (testimony of Judge Becker). In the Antibiotic Drug litigation, in which the burden of handling both the settling and nonsettling cases became too great for one judge, the Panel assigned the latter group of cases to a new transferee judge. In re Antibiotic Drugs, 320 F. Supp. 586 (J.P.M.L. 1970). The transferee judge was also replaced in the Plumbing Fixtures litigation. Philadelphia Housing Authority v. American Radiator \& Standard Sanitary Corp., 323 F. Supp. 364 (E.D. Pa. 1970). In In re Penn Central Sec. Litigation, 325 F. Supp. 309, 311 n.2 (J.P.M.L. 1971), the Panel found it impossible for one judge to conduct pretrial proceedings efficiently in both conflicting groups of cases and remanded the commercial paper cases, assigning them to another transferee district.

55 The Fourth Transferee Judge Meeting was held in Chandler, Arizona, in December, 1971. Materials on file at The University of Chicago Law Review.

56 In re Library Editions of Children's Books, 299 F. Supp. 1139, 1141 (J.P.M.L. 1969).

57 Id.

6828 U.S.C. $\$ 1406$ (a) (1970) provides that a district court may dismiss or, if in the interest of justice, transfer a case laying venue in the wrong district to any district in which it could have been brought.

59 Goldlawr, Inc. v. Heiman, 369 U.S. 463 (1962) (section 1406(a)); United States v. Berkowitz, 328 F.2d 358 (3d Cir. 1964) (section 1404(a)).

60 The Panel is aware of the charge that plaintiffs have filed the same complaint in different districts in order to necessitate multidistrict transfer and thereby avoid the venue requirements of antitrust law. Proper venue, however, is not a criterion for deciding the propriety of section 1407 transfer. In re Hotel Tel. Charge Antitrust Litigation, MDL. Docket No. 89 (J.P.M.L., filed Mar. 30, 1972). 
must be made on each defendant. Even if a party were served after transfer, he might still raise any motions available to a party served before transfer, including motions to quash service or to dismiss for want of jurisdiction. Although it was initially unclear in which forum such motions should be made, transferee courts have since routinely considered them. ${ }^{01}$

Subsequent decisions of transferee courts demonstrate that violation of technical venue and service requirements will not normally prevent a party's inclusion in centralized pretrial proceedings. In the Children's Books litigation, ${ }^{62}$ the defendants brought motions in the transferee court to quash service of process and to dismiss for improper venue. Although the court held that venue was improper as to some defendants, it did not dismiss the actions, but instead severed them from the main body of the litigation and announced that it would exercise its authority under section 1406(a) to transfer them to a district of proper venue after pretrial proceedings were completed.

One of the factors influencing transferee courts in denying motions to dismiss for improper venue is that dismissal or transfer to a proper district before the completion of pretrial proceedings will usually result in immediate retransfer of the actions to the transferee district as "tagalong" cases. In Maricopa County v. American Petrofina, Inc., ${ }^{83}$ the transferee court refused to quash defective service, despite the fact that the summons was unsigned, undated, and unsealed. The court noted that upon dismissal the plaintiffs could always obtain a valid service, and the action would then be retransferred, gaining the defendant nothing but time. Discovery would meanwhile be going forward in all other cases; and to the extent that related cases were not included in pretrial proceedings, the benefits of coordination or consolidation would be diminished. The court therefore held the defendant estopped from asserting that service was improper. ${ }^{64}$

61 Initially, the Judicial Panel did not indicate whether transferor or transferee courts should decide such motions. In re Library Editions of Children's Books, 299 F. Supp. 1139, 1142 n.l (J.P.M.L. 1969). In re Gypsum Wallboard, 302 F. Supp. 794 (J.P.M.L. 1969), noted that transferee judges were deciding such motions, citing Monkelis v. Trans World Airlines, Inc., 303 F. Supp. 651 (E.D. Ky. 1969) (Cincinnati Air Crash) (third-party complaint dismissed for lack of jurisdiction over defendant). See In re Penn Central Sec. Litigation, 338 F. Supp. 438 (E.D. Pa. 1972); In re Penn Central Sec. Litigation, 338 F. Supp. 436 (E.D. Pa. 1972); Miller v. Trans World Airlines, Inc., 302 F. Supp 174 (E.D. Ky. 1969).

62 Illinois v. Harper \& Row Publishers, Inc., 308 F. Supp. 1207 (N.D. Ill. 1969); accord, ABC Great States, Inc. v. Globe Ticket Co., 310 F. Supp. 739 (N.D. IIl. 1970); Philadelphia Housing Authority v. American Radiator \& Standard Sanitary Corp., 309 F. Supp. 1053 (E.D. Pa. 1969).

63 322 F. Supp. 467 (N.D. Cal. 1971) (Western Liquid Asphalt).

64 See In re Koratron Patent Litigation, 314 F. Supp. 60 (J.P.M.L. 1970). A suit was 
Jurisdictional defects, as opposed to technically improper service, notice, or venue, remain a major exception to the transferee courts' broad inclusionary policy. Since section 1407 did not expand the territorial limits of effective service, ${ }^{65}$ a party not subject to the jurisdiction of the transferor court but amenable to service in the transferee district may not be joined to an action by service in the transferee district after transfer. In Allegheny Airlines, Inc. v. LeMay, ${ }^{\circ 6}$ a third-party complaint against a party not subject to suit in the transferor court was dismissed for want of personal jurisdiction, even though the party could have been served in the transferee district. Save for this limitation, however, transferee courts are very reluctant to delay pretrial proceedings in any case that will eventually be subject to transfer.

\section{Injunctive Relief}

Although the transferee court can grant injunctive relief as part of normal pretrial proceedings, ${ }^{67}$ a motion for a preliminary injunction could involve substantial discovery and upset the pretrial schedule adopted at the pretrial conferences. ${ }^{68}$ The transferee judge, controlling the entire litigation, will not issue an injunction unless it would not interfere with the rights of other parties to coordinated or consolidated pretrial proceedings. ${ }^{69}$

\section{Settlements}

Multidistrict litigation may be teminated by settlement in the transferee court, and widespread settlement activity has taken place under the supervision of transferee judges. ${ }^{70}$ Negotiated settlements of litigation

dismissed for improper venue, but while the appeal was still pending (subsequently affirmed in Koratron Co. v. Lion Uniform, 449 F.2d 337 (9th Gir. 1971)), an identical case was filed in a district of proper venue and was retransferred to the transferee district as a tag-along case.

65 In re Library Editions of Children's Books, 299 F. Supp. 1139, 1142 (J.P.M.L. 1969).

66448 F.2d 1341 (7th Cir. 1971) (Mid-Air Crash near Fairland, Ind.).

67 See American Bible Soc'y v. Blount, 446 F.2d 588 (3d Cir. 1971) (Fourth Class Postage Regulation); In re International House of Pancakes Franchise Litigation, 5 Trade REg. REP. (1972 Trade Cas.) If 73,797 (W.D. Mo. Jan. 4, 1972).

68 Control Data Corp. v. IBM, 1970 Trade Cas. 89,162 (D. Minn. 1970).

69 Id.; see also In re Motor Vehicle Air Pollution Control Equip., 1970 Trade Cas. 89,254 (G.D. Cal. 1970).

70 See Panel Rule 15(e). Major settlements have occurred in the following cases: Lindy Bros. Builders, Inc. v. American Radiator \& Standard Sanitary Corp., 5 Trade Reg. Rep. (1972 Trade Cas.) I 73,953 (E.D. Pa. Apr. 28, 1972); In re Revenue Properties Co., MDL Docket No. 32 (D. Mass., filed Jan. 26, 1972); Hartford Hosp. v. Chas. Pfizer \& Co., 52 F.R.D. 131 (S.D.N.Y. 1971); West Virginia v. Chas. Pfizer \& Co., 314 F. Supp. 710 (S.D.N.Y. 1970), aff'd, 440 F.2d 1079 (2d Cir. 1971), cert. denied, 404 U.S. 871 (1971) (Antibiotic Drugs); Philadelphia Housing Authority v. American Radiator \& Standard Sanitary Corp., 323 F. Supp. 364 (E.D. Pa. 1970), settlement approved, 322 F. Supp. 834 (E.D. Pa.), aff'd sub. nom. 
involving class action claims, however, have proved very difficult to administer. Transferee judges have had to determine appropriate class definitions, adequate class representatives, and proper notice and exclusion procedures; ultimately, they have had to approve the fairness of the compromise agreement, weighing the difficulty of prevailing on the merits at trial against the size of the award. ${ }^{71}$ After final approval of the settlement, the transferee judge must retain jurisdiction to supervise distribution of the fund to class members, proof of claims, and determination of expenses and legal fees. ${ }^{22}$ Only upon resolution of these problems will the court enter final judgment for the defendants and dismiss the actions.

\section{E. Dismissal and Summary Judgment}

As authorized by the Judicial Panel's rule 15(d), transferee courts routinely consider motions to dismiss transferred cases. ${ }^{73}$ Since such motions are usually considered before trial, they constitute pretrial proceedings within the jurisdiction of the transferee judge.

Although pretrial transfer is based on the existence of common questions of fact, transferee courts frequently resolve common questions of law by summary judgment. ${ }^{74}$ The legislative history of section 1407 clearly empowers transferee judges to exercise the summary judgment power, ${ }^{75}$ but the drafters regarded this power as essential to the trans-

Ace Heating \& Plumbing Co. v. Crane Co., 453 F.2d 30 (3d Cir. 1971); Penn Central Commercial Paper Litigation, Wall Street Journal, Apr. 27, 1972, at 20, col. 4 (Midwest ed.).

For a discussion of the propriety of allowing attorney fees and expenses in the creation of a settlement fund in multidistrict cases, see Lindy Bros. Builders, supra.

71 West Virginia v. Chas. Pfizer \& Co., 314 F. Supp. 710, 740-41 (S.D.N.Y. 1970).

72 Hartford Hosp. v. Chas. Pfizer \& Co., 52 F.R.D. 131, 138 (S.D.N.Y. 1971); West Virginia v. Chas. Pfizer \& Co., 314 F. Supp. 710 (S.D.N.X. 1970).

73 E.g., Dorfman v. First Boston Corp., 336 F. Supp. 1089 (E.D. Pa. 1972) (Penn Central Securities) (motions to dismiss for failure to state a claim granted in part); In re Antibiotic Antitrust Actions, 333 F. Supp. 315 (S.D.N.Y. 1971) (motion to dismiss denied); In re Antibiotic Antitrust Actions 333 F. Supp. 296 (S.D.N.Y. 1971), aff'd, 450 F.2d 1119 (2d Cir. 1971) (motion to dismiss for res judicata granted); In re Motor Vehicle Air Pollution Control Equip., 52 F.R.D. 398 (C.D. Cal. 1970) (motion to dismiss for impropriety of maintaining class actions granted); Philadelphia Housing Authority v. American Radiator \& Standard Sanitary Corp., 50 F.R.D. 13 (E.D. Pa. 1970), aff'd sub. nom. Mangano v. American Radiator \&. Standard Sanitary Corp., 438 F.2d 1187 (3rd Cir. 1971) (motion to dismiss for failure to answer interrogatories granted).

74 E.g., In re Antibiotic Antitrust Actions, 333 F. Supp. 313 (S.D.N.Y. 1971); In re Antibiotic Antitrust Actions, 333 F. Supp. 310 (S.D.N.Y. 1971); Jack Winter, Inc. v. Koratron Co., 329 F. Supp. 211 (N.D. Cal. 1971); Jack Winter, Inc. v. Koratron Co., 327 F. Supp. 206 (N.D. Cal. 1971); Maricopa County v. American Radiator \& Standard Sanitary Corp., 323 F. Supp. 381 (E.D. Pa. 1970); See In re Gypsum Wallboard, MDL Docket No. 14 (J.P.M.L., filed Apr. 7, 1972).

75 H.R. REP. No. 1130, supra note 17, at 3; see note 43 supra. 
feree court's ability to conduct discovery effectively. ${ }^{76}$ Since the actions would be remanded to transferor courts for trial on the issues defined in pretrial proceedings, ${ }^{77}$ it was the function of the transferee judge to create a body of facts on which the transferor judges could eventually base their determinations of the legal issues. ${ }^{78}$ Threshold legal questions, therefore, had to be disposed of early in pretrial proceedings so that the scope of discovery would be narrowed. ${ }^{79}$

By insisting on the remand of transferred cases, the drafters of section 1407 demonstrated that they never intended transferee judges to exercise the summary judgment power after completion of pretrial discovery. Yet in several recent cases, transferee judges have assumed the power to so rule. ${ }^{80}$ In disposing of the litigation in this fashion, transferee courts arguably preempt the function the drafters envisioned for transferor courts. ${ }^{81}$ The narrow statutory language does not, however, explicitly prevent the exercise of this power, since until the cases are actually remanded, transferee judges may consider any pretrial motions, including those for summary judgment. Moreover, a broad summary judgment power for transferee courts is consistent with the purpose of section 1407 to provide a mechanism for more efficient disposition of related multidistrict cases. If no genuine disputed issues of fact exist, it would be wasteful of judicial resources for the transferee court to remand the cases to scattered transferor courts, enabling judges unfamiliar with the litigation to rule independently on identical questions of law. Conflicting decisions on remand, moreover, would defeat the consistency achieved by pretrial transfer. The transferee court is the most practical forum for resolving these questions, and a broad summary judgment power provides the best method for disposing of the litigation.

Similar considerations of efficiency have influenced the Judicial Panel to transfer multidistrict cases sharing common questions of law

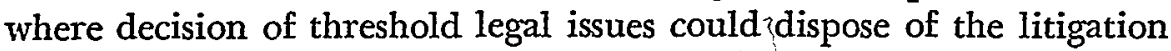

76 See note 43 supra, in which the power to make legal rulings is discussed in terms of its indispensability for the efficient conduct of pretrial proceedings.

77 H.R. REP. No. 1130, supra note 17, at 4; see Hearings on S. 3815, supra, note 21, at 20-21 (testimony of Judge Becker). Debate at the time of passage of section 1407 also concerned the mandatory nature of the remand requirement. See 113 CoNG. REc. 22123 (1967).

78 See Control Data Corp. v. IBM, 306 F. Supp. 839, 852 (D. Minn. 1969); Hearings on S. 3815 , stcpra note 21 , at 23 (testimony of Judge Becker).

79 Hearings on $S .3815$, supra note 21, at 22 (testimony of Judge Becker).

80 E.g., Reidinger v. Trans World Airlines, Inc., 329 F. Supp. 487 (E.D. Ky. 1971) (Cincinnati Air Crash) (after completion of discovery, summary judgment for plaintiff granted on issue of negligence); Jack Winter, Inc. v. Koratron Co., 327 F. Supp. 206 (N.D. CaI. 1971) (summary judgment denied on issue of patent validity because reasonable doubt existed on other factual issues).

81 See note 78 supra. 
without extensive discovery. ${ }^{82}$ Although the statutory criterion is literally satisfied by the presence of common factual questions, the factual issues often serve as a pretext for the resolution of common legal questions. ${ }^{83}$ Actions sharing only common legal questions were not thought by the drafters to require the same intensive pretrial discovery and the same need for consultation and communication among district judges and were specifically exempted from section 1407 transfer. ${ }^{84}$ The Panel's rationale, however, that transfer of these cases permits optimal use of judicial manpower and serves the interest of the parties by eliminating separate resolution of identical motions, ${ }^{85}$ is consistent with the broad purpose of section 1407.

\section{F. Class Action Claims}

The most difficult function of the transferee judge is the resolution of conflicting class action claims. Independent consideration of class definitions and representation would pose the most serious threat of conflicting contemporaneous district court rulings, and failure to consolidate for pretrial proceedings would create the overload in the district courts that section 1407 was designed to avert. ${ }^{86}$

The Judicial Panel itself cannot resolve conflicting class action claims, ${ }^{87}$ nor can the question whether a class action is maintainable be separated from the rest of the litigation and reserved for determination by the transferor court. ${ }^{88}$ Section 1407(a) provides for transfer of civil

82 Levy, supra note 6, at 48; Comment, Pre-Trial Consolidation in Complex Federal Multi-District Litigation, supra note 8, at 439-40.

83 Broad interpretation of what constitutes "common questions of fact" dilutes this limitation of the Panel's ability to transfer cases. In re Fourth Class Postage Regulations, 298 F. Supp. 1326 (J.P.M.L. 1969), is widely construed as a case in which transfer, although justified by tangential factual inquiries into the operations of the postal system, was actually granted in order to decide the constitutionality of the statute, a purely legal question. The crucial question in In re Air Fare Litigation, 322 F. Supp. 1013 (J.P.M.L., 1971), was the legality of the approved fare increases; the only common factual questions justifying transfer related to damages, particularly the definition of the classes entitled to recovery.

84 Hearings on S. 3815, supra note 21, at 16 (testimony of Judge Becker).

85 Thus, in In re Butterfield Patent Infringement, 328 F. Supp. 513 (J.P.M.L. 1970), a compelling reason for transfer was the lurking possibility of summary judgment on the questions of patent validity and laches. And in In re Suess Patent Infringement Litigation, 331 F. Supp. 549 (J.P.M.L. 1971), two infringement cases had been tried before a judge on the question of collateral estoppel. The Panel transferred another case to his docket for resolution of the patent validity and collateral estoppel questions in all related cases.

88 In re Plumbing Fixtures, 298 F. Supp. 484, 493 (J.P.M.L. 1968). For a discussion of settlements in multidistrict litigation involving class action claims, see text at notes $71-72$ supra.

87 In re Four Seasons Sec. Laws Litigation, 328 F. Supp. 221, 223 n.2 (J.P.M.L. 1971).

88 In re Plumbing Fixtures, 298 F. Supp. 484, 488-89 (J.P.M.L. 1968). Nor can the com- 
actions, not parts thereof; by withholding the power to separate issues from the Panel, its drafters required that transferee courts decide class action claims. ${ }^{89}$

The overlap between claims and the classes attempting to assert them requires constant judicial scrutiny to prevent the possibility of inconsistent rulings and recoveries. ${ }^{90}$ With all claims pending before a single judge, the litigation can more easily be amalgamated into manageable units and disposed of in an orderly fashion. ${ }^{91}$ The transferee judge can choose among competing classes and among potential representatives to insure that all maintainable claims and eligible classes participate in the ultimate trial. His restructuring of the disjointed actions into what can be termed a "super class action" may be the only form in which the litigation can be handled by the judicial system. The pressure for transferee court disposition of these cases and the prevention of their atomization through remand is overwhelming. ${ }^{92}$ The creation of an orderly scheme for resolution of claims militates against their dismemberment and piecemeal consideration..$^{33}$

The best illustration of the indispensability of multidistrict transfer and the awesome burden faced by transferee judges is the Antibiotic

plexities of overlapping class allegations be left to the voluntary cooperation of the parties. In re Hotel Tel. Charge Antitrust Litigation, MDL Docket No. 89, filed Mar. 30, 1972).

89 Id. at 490.

90 In re Antibiotic Antitrust Actions, 333 F. Supp. 299, 301-02 (J.P.M.L. 1971).

91 Conflicting class action claims constitute a substantial proportion of the litigation handled by transferee judges and are heavily concentrated in the antitrust and securities areas. While the statute was not drafted exclusively to deal with these areas, the efficiencies of pretrial transfer appear greatest therein, since discovery is more complex and extended.

Twenty-two of the fifty-three transferred dockets, including seven of eight securities cases and fourteen of nineteen antitrust cases, involve class action claims. The patent and disaster areas are not usually suited for the maintenance of class actions. But see text at note 127 infra.

92 In no reported cases have class action claims been remanded to the transferor courts for trial.

93 Transferee courts have decided the following issues in cases involving class action claims:

Inclusion of parties within previously determined classes: E.g., In re Antibiotic Antitrust Actions, 333 F. Supp. 296 (S.D.N.Y. 1971); Indiana v. Chas. Pfizer \& Co., 51 F.R.D. 493 (S.D.N.Y. 1970); Burlington Hosp. v. Chas. Pfizer \& Co., 48 F.R.D. 343 (S.D.N.Y. 1969).

Adequacy of class representation: E.g., Barkal v. Chas. Pfizer \& Co., 51 F.R.D. 504 (S.D. N.Y. 1970).

State parens patriae representation of its citizens: E.g., In re Antibiotic Antitrust Actions, 333 F. Supp. 278 (S.D.N.Y. 1971); In re Motor Vehicle Air Pollution Control Equip., 52 F.R.D. 398 (C.D. Cal. 1970).

Notice and exclusion problems: Pfizer, Inc. v. Lord, 449 F.2d 119 (2d Cir. 1971); Illinois v. Harper \& Row Publishers, Inc., 301 F. Supp. 484, 494 (N.D. IIl. 1969); see text at notes 100-01 infra. See generally Handler, Twenty-fourth Annual Antitrust Review, 72 Colum. L. Rev. 1 (1972). 
Drugs litigation. ${ }^{94}$ Multiple civil treble damage suits were filed following a successful criminal prosecution in which the defendant antibiotic drug manufacturers were convicted of conspiracy to fix prices and to exclude competitors in violation of the Sherman Act. ${ }^{95}$ The Judicial Panel transferred over three hundred such actions, including many class action claims, to the Southern District of New York..$^{96}$ While discovery proceeded, sixty-six governmental bodies, suing as class representatives of state and county hospitals and the consuming public, accepted the defendants' initial settlement offer. ${ }^{97}$ The transferee judge approved the $\$ 100$ million damage agreement as fair and equitable and established temporary classes of participating states, hospitals, and retail purchasers to share in its distribution. Jurisdiction was reserved to oversee administration of the fund. Similar agreements amounting to $\$ 32.5$ million were subsequently reached with nineteen private hospitals, also suing as class representatives..$^{98}$ Since the task of administering these agreements and directing ongoing discovery in the nonsettling cases was too burdensome for one man, the Panel assigned the latter cases to another judge for completion of pretrial proceedings. ${ }^{99}$

The new transferee judge subsequently established nonsettling government entity classes and retail consumer classes, ${ }^{100}$ approved and ordered distribution of notice and exclusion forms, and decided several critical questions involving the tolling of the statute of limitations and the remoteness of certain claims. ${ }^{101} \mathrm{He}$ finally concluded that the overlap between classes and the possibility of inconsistent recoveries could be resolved only through a planned sequence of trials, ${ }^{102}$ thus illustrating the impossibility of fully resolving all conflicting claims even in consolidated pretrial proceedings. Without such proceedings, however, even partial resolution of these problems could not have been accomplished without chaotic, inconsistent decisions. The experience of the Antibiotic Drugs cases indicates why pretrial transfer of class action claims is a valuable, albeit often incomplete, attempt to conduct multidistrict litigation efficiently and expeditiously.

04 See notes 95-102 infra.

95 United States v. Chas. Pfizer \& Co., 281 F. Supp. 837 (S.D.N.Y. 1968), rev'd for new trial, 426 F.2d 32 (2d Cir. 1970), aff'd, 92 S. Ct. 731 (1972).

98 In re Antibiotic Drugs, 295 F. Supp. 1402 (J.P.M.L. 1968).

97 West Virginia v. Chas. Pfizer \& Co., 314 F. Supp. 710 (S.D.N.Y. 1970).

98 Fartford Hosp. v. Chas. Pfizer \& Co., 52 F.R.D. 131 (S.D.N.Y. 1971).

99 In re Antibiotic Drugs, 320 F. Supp. 586 (J.P.M.L. 1970).

100 In re Antibiotic Antitrust Actions, 333 F. Supp. 291 (S.D.N.Y. 1971); In re Antibiotic Antitrust Actions, 333 F. Supp. 274 (S.D.N.Y. 1971).

101 In re Antibiotic Antitrust Actions, 333 F. Supp. 310 (S.D.N.Y. 1971); In re Antibiotic Antitrust Actions, 333 F. Supp. 278 (S.D.N.Y. 1971).

102 In re Antibiotic Antitrust Actions, 333 F. Supp. 299, 301-02 (S.D.N.Y. 1971). 


\section{G. Section 1404(a) Transfers}

Section 1404(a) authorizes transfer of any civil action to any other district where it might have been brought if the district court finds that it would promote the convenience of parties and witnesses and the interest of justice. ${ }^{103}$ Multidistrict transfer and change of venue are complementary techniques of judicial management, permitting consolidation of cases for trial after completion of pretrial proceedings under section $1407 . .^{104}$ Originally, the Judicial Panel stated that an "appropriate" court could consider section 1404(a) motions, without specifying whether transferee or transferor courts had such jurisdiction. ${ }^{105}$ Section 1407 is completely silent on this point, but the apparently mandatory nature of the remand clause, which provides that each case shall be remanded to the transferor court unless previously terminated in the transferee court, ${ }^{106}$ implies that transferee courts lack this jurisdiction.

Nevertheless, in its promulgation of Rule 15(e), the Judicial Panel concluded that transferee judges have authority to order such transfers for consolidated trial. ${ }^{107}$ Simultaneously, transferee judges have held that they possess the power to transfer cases under section 1404(a), ${ }^{108}$ reasoning that the remand requirement defines and limits the jurisdictional powers of the Judicial Panel, not those of transferee judges. ${ }^{109} \mathrm{Al}$ though the Panel would have no authority to transfer cases for trial, change-of-venue motions fall within the ambit of pretrial proceedings over which transferee judges have jurisdiction. ${ }^{110}$ Thus, transferee

10328 U.S.C. \& 1404(a) (1970).

104 In re Grain Shipments, 300 F. Supp. 1402 (J.P.M.L. 1969).

105 Id. at 1404. Earlier, in In re Mid-Air Collision near Hendersonville, N.G., 297 F. Supp. 1039, 1040 (J.P.M.L. 1969), the Panel noted that the transferor judge could consider a section 1404(a) motion upon the completion of pretrial proceedings after remand.

10628 U.S.C. \& 1407(a) (1970).

107 Panel Rule 15(e) provides: "Each transferred action that has not been terminated in the transferee court will be remanded to the transferor district for trial, unless ordered transferred by the transferee judge to the transferee or other district under 28 U.S.C. \$ 1404(a) or 28 U.S.C. \$ 1406. In the event that the transferee judge transfers an action under 28 U.S.C. $\$ \$ 1404$ (a) or 1406, an order of remand shall not be necessary to authorize further prớcéedings including trial."

108 In re Antibiotic Antitrust Actions, 333 F. Supp. 309 (S.D.N.Y. 1971) (animal feed cases); In re Antibiotic Antitrust Actions, 333 F. Supp. 299 (S.D.N.Y. 1971), aff'd sub. nom. Pfizer, Inc. v. Lord, 447 F.2d 122 (2d Gir. 1971) (human consumption cases); In re Hanover, N.H. Air Crash Disaster, MDL Docket No. 43 (D.N.H., filed June 3, 1971); Illinois v. Harper \& Row Publishers, Inc., MDL Docket Nos. 2, 4, 5, 6, 7 (N.D. Ill., filed Mar. 23, 1971); Jack Winter, Inc. v. Koratron Co., 326 F. Supp. 121 (N.D. Cal. 1971).

109 Pfizer, Inc. v. Lord, 447 F.2d 122, 124 (2d Cir. 1971).

110 Jack Winter, Inc. v. Koratron Co., 326 F. Supp. 121 (N.D. Cal. 1971), was actually decided on this ground; the other four cases rely on the porver of the transferee judge and on the rules of the Panel. 
judges have transferred to their own dockets for trial cases previously centralized only for pretrial proceedings. ${ }^{111}$

In considering a section 1404(a) motion, a transferee judge tends to employ standards different from those of a transferor judge. ${ }^{112}$ Because of his familiarity with the entire litigation, the transferee judge usually takes a broad perspective, weighing the interests of all parties and of efficient judicial administration in transfer. ${ }^{113} \mathrm{~A}$ transferor judge, in contrast, would consider only the interests of the parties in the case immediately before him. Since efficiency is promoted by having the same judge conduct both pretrial proceedings and the trial, the transferee judge is more likely to order transfer of multidistrict cases to his own docket for trial. Yet this decision introduces a factor not normally considered in deciding a section 1404(a) motion, the convenience of the transferee judge. 114

Transfers by transferee judges to their own dockets for trial seem to evade the original understanding of the drafters that pretrial transfer would not affect the place of trial of any action; ${ }^{115}$ under current practice, section 1407 transfers often conclusively determine in which district the actions will be tried. In general, transferee judges have used their powers to control the ultimate disposition of transferred cases. Analysis focusing solely on the pretrial implications of their activity ignores the trend of transferee court rulings in multidistrict cases; the true importance of section 1407 transfer is in its impact on the final resolution of transferred cases. Section 1404(a) transfers most forcefully pose the crucial question to what extent transferee court judges should be permitted to retain coordinated or consolidated cases beyond the pretrial stage.

\section{Expansion of Multidistrict Transfer Beyond Pretrial Proceedings}

\section{A. Devices Adopted by Transferee Judges}

The outstanding operational effect of section 1407 has been the absence of actions remanded after the completion of pretrial proceedings; ${ }^{116}$ transferee courts have usually attempted to decide all substantive

111 Transferee judges can transfer cases to districts other than their own for trial under section 1404(a). See In re IBM, MDL Docket No. 18 (J.P.M.L., filed Apr. 19, 1972).

112 Levy, supra note 6, at 63-65; Comment, Pre-Trial Consolidation in Complex Federal Multi-District Litigation, supra note 8, at 443.

113 Levy, supra note 6, at 63.

114 Id.

115 H.R. REP. No. 1130, supra note 17, at 3.

116 The only reported use of the remand provision is in In re Penn Central Sec. Litigation, 325 F. Supp. 309, 311 n.2 (J.P.M.L. 1971), in which two previously transferred com- 
issues in the litigation. Although this objective may be desirable in some cases, the procedures currently employed have proven unsatisfactory. Of the methods available, the most direct is by summary judgment where there are no disputed issues of fact. ${ }^{117}$ Another possible procedure is transfer of cases under section 1404(a) to the transferee judge's regular docket for trial. ${ }^{118}$ This method, however, is of only limited utility, since consolidation is impossible for actions that could not have been brought originally in the transferee district. ${ }^{119}$

A third method for deciding substantive issues is through consent of the parties. Since trial on a threshold legal issue can be held in a case originally commenced in the transferee court, the result of that trial could be made binding on the parties in the transferred cases by stipulation. ${ }^{120}$ This technique proved successful in the Butterfield Patent litigation. ${ }^{121}$ After completion of discovery in all cases, many defendants whose actions had been transferred for pretrial proceedings consented to having their cases tried by the transferee judge on the narrow issue of patent validity. The patent was declared invalid, terminating the litigation for consenting parties and establishing a strong precedent for the other pending cases. Also, in the Santa Monica Air Crash litigation, ${ }^{122}$ counsel in the transferred cases agreed to consolidated trial before the transferee judge; the defendant aircraft manufacturer was found not to have been negligent, and the litigation was terminated.

A fourth method of disposition involves an intercircuit assignment of the transferee judge to the transferor districts to try cases remanded there. In the CBS Color Tube Patent litigation, ${ }^{123}$ the Panel concluded that it would be possible to assign the transferee judge temporarily under section 292(c) ${ }^{124}$ to any district in which a trial must be held.

mercial paper cases were separated from promissory note cases by the Judicial Panel and were transferred to another district along with other similar cases for coordinated or consolidated pretrial proceedings. See In re Penn Central Commercial Paper Litigation, 337 F. Supp. 1335 (J.P.M.L. 1972). Frequently, remand requests are filed before the Panel as tardy objections to transfer of tag-along cases. E.g., In re Plumbing Fixtures, 332 F. Supp. 1047 (J.P.M.L. 1971); In re Revenue Properties Co., 314 F. Supp. 1255 (J.P.M.L. 1970). The Panel will remand an action or separable claim prior to the completion of pretrial proceedings only upon a showing that remand would promote the just and efficient conduct of the litigation. In re Gypsum Wallboard, MDL Docket No. 14 (J.P.M.L., filed Apr. 7, 1972) (remand denied for lack of showing of good cause).

117 See text at notes 74-85 supra.

118 See text at notes 103-15 supra.

119 See note 15 supra.

120 Jack Winter, Inc. v. Koratron Co., 327 F. Supp. 206, 210-11 (N.D. Cal. 1971); In re Grain Shipments, 325 F. Supp. 318, 319-20 n.4 (J.P.M.L. 1971).

121 Butterfield v. Oculus Contact Lens Co., 332 F. Supp. 750 (N.D. I11. 1971).

$122 \mathrm{MDL}$ Docket No. 34 (C.D. Cal., filed Dec. 15, 1971).

123329 F. Supp. 540, 541 n.3 (J.P.M.L. 1971).

12428 U.S.C. $\S 292$ (c) (1970). 
This device was used in the Antibiotic Antitrust Actions; ${ }^{125}$ the transferee judge was assigned to the Northern District of California for the purpose of trying the cases originally commenced in that district.

These final two devices, stipulation and intercircuit assignment, also have serious limitations. Consent of all parties to trial in the transferee district cannot always be obtained, and, as in the Butterfield Patent litigation, a substantial number of parties may refuse to join. ${ }^{126}$ Intercircuit transfers, on the other hand, are time-consuming and administratively burdensome. If they were widely used, the transferee judge would become a nationwide circuit rider, unable to supervise his normal docket of cases.

Whatever their effectiveness, these judicially devised methods of consolidation represent attempts to continue the efficiencies of centralized management past the completion of pretrial proceedings. The practical effect of these procedures is to permit trial of common issues in multidistrict cases as if the litigation were a class action. ${ }^{227}$ The resources and expertise of the parties can be pooled for more vigorous prosecution of the disputed issues of law and fact, but with substantial time and cost savings to all parties.

Transferee judges have failed, however, in their attempts to create a mechanism to achieve the benefits of consolidated trial wherever concentration past the pretrial stage is desirable. What is required, therefore, is amendment of the statute to so provide. The two primary questions to be resolved in designing this modification are in which cases consolidated trial is appropriate and what method should be used to effectuate their consolidation.

\section{B. The Appropriateness of Consolidated Trial}

Although trial on issues common to all cases can produce time and cost benefits similar to those accruing from coordinated or consolidated pretrial proceedings, transfer for trial would not always be desirable in

125 In re Antibiotic Antitrust Actions, 333 F. Supp. 299, 301 (S.D.N.Y. 1971).

128 This was one of the strongest reasons put forth at the Senate hearings in justification of the creation of mandatory pretrial transfers. The same argument would apply to transfer for trial purposes. See Hearings on S. 3815, supra note 21, at 28 (testimony of Charles A. Bane).

127 "The cases tried [after transfer] will be tried in the same manner as a class action. The plaintiffs' attorneys will determine which of them will try the case. For purposes of trial, the court considers the appearance of an attorney in one case as an appearance in all cases." In re Hanover, N.H. Air Crash Disaster, MDL Docket No. 43 (D.N.H., filed June 3, 1971). But see Hobbs v. Northeast Airlines, Inc., 50 F.R.D. 76 (E.D. Pa. 1970), in which a transferor judge had already ruled that these mass tort wrongful damage claims were not suitable for treatment as a class action. The effect of the transferee court ruling was to allow trial of these claims as a class action, but only with respect to the issue of liability. 
all cases in which pretrial transfer is appropriate. Certain issues, such as individual damages, can best be tried in the transferor district, where most witnesses and evidence are readily available. ${ }^{128}$ Moreover, separate trials on multiple individual damage claims in the transferee court would be likely to impose a heavy burden on the transferee judge and impair his capacity to try other litigation. ${ }^{129}$

In cases involving common disasters, for example, although the question of liability can usually be resolved on a consolidated basis, it is more practical to remand each case to the transferor district for trial on the individual damage claims. ${ }^{130}$ Since most evidence relevant to the deceased's earnings potential and life expectancy is located in that district, the inconvenience and expense of travel for witnesses are avoided. This technique was adopted in the Hanover Air Crash litigation, ${ }^{131}$ in which the transferee judge transferred the cases consolidated for pretrial purposes to his own docket under section 1404(a) for trial, but only on the question of liability. The question of damages was explicitly reserved for local discovery and trial in the transferor courts after remand. ${ }^{132}$

Even if there is a common factual background, the legal claims of the parties may be so incompatible that it would be impossible to coordinate the cases past the initial stages of discovery. ${ }^{133}$ In these situations, the cases might be separated into manageable categories and set for trial independently; after pretrial proceedings, they could be transferred to the appropriate districts for trial. ${ }^{134}$

The mere fact that actions were transferred for coordinated or consolidated pretrial proceedings does not conclusively determine that they

128 See H.R. REP. No. 1130, supra note 17, at 4; S. REP. No. 454, supra note 2, at 5.

120 S. REP. No. 454, supra note 2, at 5.

130 In re Hanover, N.H. Air Crash Disaster, MDL Docket No. 43, at 2-3 (D.N.H., filed June 3, 1971). For a critique of the application of section 1407 to disaster litigation, see McElhaney, A Plea for the "Worm's Eye View" in Multidistrict Aviation Litigation, 37 J. AIr -L. \& Com. 49 (1971); Seeley, Procedures for Coordinated Multidistrict Litigation: A Nineteenth Century Mind Views With Alarm, 14 Anrrtrusr Burc. 91 (1969).

131 In re Hanover, N.H. Air Crash Disaster, MDL Docket No. 43 (D.N.H., filed June 3, 1971).

132 Id. at 1-2.

133 These would typically be cases in which the claims of various groups of plaintiffs required proof of contradictory points. See cases cited note 50 supra.

134 This separation would not prevent the transferee judge from trying all groups of cases. The human consumption and animal feed cases in the Antibiotic Drug litigation, for example, were separately transferred to the District of Minnesota for trial by the tranferee judge. In re Antibiotic Antitrust Actions, 333 F. Supp. 309 (S.D.N.Y. 1971) (animal feed cases); In re Antibiotic Antitrust Actions, 333 F. Supp. 299 (S.D.N.Y. 1971) (human consumption cases). But see In re IBM, MDL Docket No. 18 (J.P.M.L., filed Apr. 19, 1972). 
should be tried in a consolidated fashion. ${ }^{135}$ Subsequent separation and transfer will insure that the actions are tried justly and efficiently, but without sacrificing the convenience of the parties to the litigation.

\section{A Statutory Proposal}

If transfer of multidistrict litigation for purposes of trial is to be permitted, it must necessarily be without regard to venue in order that all related cases might be consolidated for trial if efficiency so demanded. A single decision maker must determine the propriety of transfer in such cases. The Judicial Panel could make such a decision, either as part of its order after the initial transfer hearing or at the completion of pretrial proceedings. The transferee judge, however, could make a more precise evaluation of the problems revealed in the litigation; at the completion of pretrial proceedings, he could more accurately determine the degree of subsequent consolidation that would be most just and efficient, considering both the convenience of the parties and the economies to the judiciary. Specifically, he could determine how much of a burden consolidated trial would be on his responsibilities in his own district. If consolidated trial were not appropriate, he could then remand the cases to their original districts according to the present statutory mechanism. This two-level transfer scheme thus permits initial consideration of the desirability of pretrial transfer by the Judicial Panel, but requires subsequent evaluation of the benefits obtainable from consolidated trial in the light of problems arising during pretrial proceedings.

The House Report noted that section 1407 was drafted so that it could easily be amended to provide for coordinating or consolidating cases for trial as well as pretrial proceedings, if experience so suggested. ${ }^{\mathbf{1 3 6}}$ Pretrial transfer generates great savings in time and expense, but, as transferee judges have intuitively recognized in going beyond the intent of the present law, dramatic efficiencies in judicial administration can often be realized through further consolidation for trial. The Multidistrict Litigation Act should be amended to provide a coherent and workable mechanism to replace the tentative efforts of transferee courts to extend the principles of centralized practice beyond the pretrial stage.

John F. Cooney

135 In some cases, however, the Panel selects the transferee district best able to serve as the trial forum. In re Yarn Processing Patent Validity Litigation, 341 F. Supp. 376 (J.P.M.L. 1972).

13 B.R. REP. No. 1130, supra note 17, at 4. 